\title{
Electronic Banking in Opinion of Young Customers in Poland
}

\author{
Elzbieta Wyslocka ${ }^{1, *}$, Dorota Jelonek ${ }^{2}$ \\ 1,2 University Technology of Czestochowa, Poland \\ ${ }^{1}$ wyslocka@zim.pcz.pl*; ${ }^{2}$ dorota.m.jelonek@gmail.com; \\ * corresponding author
}

\begin{abstract}
The paper presents theories regarding the characteristics of consumer behavior of young customers on the basis of relevant literature and development of electronic banking in the world and in Poland. Then the methodology of conducted study and results have been described. At the end there is a summary, which presents recommendations for both practitioners and academics. Aim of this article is to determine the attitude of young consumers towards electronic banking based on a survey among the group of selected students. This seems especially important because current young consumers are increasingly better educated and are able to determine their needs very precisely. They access information quickly which enable them to determine whether the offer meets their expectations-banking services are no exception. Results of studies may help both the bank management to formulate marketing strategies to promote virtual banking and scientists in the study of virtual banks and virtual organizations in general.
\end{abstract}

Keywords: electronic banking; customers

\section{Introduction}

In recent years, a number of changes in functioning of financial institutions could be observed. They concern both defining needs of target customers and adapting banking offer to these needs. Dynamic development of information and telecommunications technology has contributed to creation of new opportunities for collection, storage and transmission of information [1,2]. It changed the picture of banks fundamentally, in particular the form of provision of banking services to customers, with an emphasis on self-service and emergence of modern services. In recent years, an important place in these services is occupied by electronic banking services.

Electronic Banking (e-banking) was defined most accurate by the Council of Electronic Banking at the Association of Polish Banks as a form of services provided by banks, which enable access to account through an electronic device: a computer, an ATM, POS terminal, phone, especially mobile, or using the telecommunication network, mainly the Internet. Basic element of electronic banking is therefore EDI, ie. Electronic data interchange, which in this case is narrowed to cooperation between client and bank, and is limited to banking services. A characteristic feature of electronic banking services (which are mostly automatic) is a lack of direct contact with the client and the bank employee. Depending on the used solution it enables to perform passive operations (eg check balances and account history) and active operations (eg making a transfer order, opening term deposit). Electronic banking is a key element of transactional banking. The specificity of electronic banking is based on the possibility of customer service: at any time, from any place with access to network, with any device allowing Internet access.

Aim of this article is to determine the attitude of young consumers towards electronic banking based on a survey among the group of selected students. This seems especially important because current young consumers are increasingly better educated and are able to determine their needs very precisely. They access information quickly which enable them to determine whether the offer meets their expectations-banking services are no exception. Scope of work is focused on explaining how young consumers nowadays perceive available market offer of banks and what are their preferences in this area. Personal scope of research concerned a group of young adults, mostly students of the Czestochowa University of Technology. Results of these studies may help both the bank management to formulate marketing strategies to promote virtual banking and scientists in the study of virtual banks and virtual organizations in general. 
This paper is organized as follows. First part presents theories regarding characteristics of consumer behavior of young customers on the basis of relevant literature and development of electronic banking in the world and in Poland. Then the methodology of conducted study and results have been described. At the end there is a summary, which presents recommendations for both practitioners and academics.

\section{Consumption Behavior of Young Clients of Electronic Banking}

In the literature, the concept of consumer behavior has been present since the middle of twentieth century. It originates from the American words "consumer behavior" and "consum behavior". Their importance was first explained by American psychologist J.C. Mowen [3], according to which consumer behavior is associated with decision-making regarding the acquisition of goods, services, experiences and ideas and consuming and disposing them. Based on this definition, business and economic psychologists at Tilburg University -G. Antonides and WF van Raaij [4] offered its own, broader recognition of the term, explaining that consumer behavior is the behavior "including mental and physical activities, together with the motives and causes, individuals and small groups concerning orientation, marketing, use and disposal of product and production of household rare goods and services by market sector, public sector and household sector; which enables the consumers to operate and achieve their goals and realize their value, and thus achieve satisfaction and well-being, taking into account short-and long-term effects of individual and social consequences. " This definition is very broad. It was developed based on years of observation of consumer behavior in the market and research on their purchasing decisions. It explains what consumer behavior really is not only through the prism of economic activity of man directed to directly meet the needs of consumers, but also taking into account the cycle of consumption and the type of market where consumers choose the most useful goods which meet their needs . Definition of G. Antonides and W. F. van Raaij [4] explain that consumer behavior reflects the process of meeting needs. Therefore, they are recognized as an organized cycle, which includes orientation, marketing, use, and at the end getting rid of the product. It concerns both mental operations that can not be directly observed, as well as physical activities.

On the basis of definition formulated by G. Antonides and W. F. van Raaij many other have been developed. Each of them in a similar way explains what consumer behavior is. In Polish literature the term is usually explained as "behavior which includes everything that precedes, occurs during and after the purchase of consumer goods and services" [5], or "process encompassing all activities related to decision-making, starting from awareness of needs and end of assessment of accuracy of consumer decisions, including exchange of information. "[6] It seems that the most relevant and accurately explaining consumer behavior definition in Polish literature was formulated by J. Szczepanski [7]. He explained that consumer behavior is "feeling needs and their assessment as well as giving preference to, or establishing their own subjective hierarchy of needs, choice of measures to meet the needs identified as more important, choice of roads to acquire these measures and handling means to meet the needs. " [7] Above-mentioned definitions show that concept of consumer behavior takes on different meanings. Based on these definitions, we can assume that consumer behavior includes the conduct of people in the process of meeting, their felt needs from the moment of determining needs, through purchase, up to use of purchased goods.

Consumer behavior in the market are different. Their analysis led to development of these behavioral theory. For the first time assumptions of this theory have been formulated in the second half of nineteenth century by English economist W. Jevons. According to them, main objectives of consumer is to meet the felt needs. It takes place through consumption of goods and services. A measure of the degree of satisfaction of these needs is the utility of goods and services, and thus a subjective pleasure resulting from their consumption. Particular good is chosen by consumer, if in his opinion it is able to satisfy its needs and at the same time allows him to derive satisfaction from the consumption or possession of the good. Theory of consumer behavior formulated in such way tries to address the question, how consumer makes the most beneficial market decisions. These decisions mean identifying goods and quantity to consume, in order to meet their own needs.

Looking at the on-line decision-making from detailed perspective models present in the theory of consumer behavior can be adapted. In theory, consumer behavior has developed a number of models taking into account decision-making process and impact of socio-psychological and cultural factors, that can put in three basic methodological approaches: decision-making approach, "experimental" approach and behavioral approach. 
Without a doubt, analysis of market behavior of consumers is a complex issue. Therefore, many authors of studies in this area show the model approach to consumer behavior. Among them it is worth paying attention to three:

- Markov model

- Bettman model

- EKB model

Markov model is a model often used in explaining consumer behavior. It is based on assumption according to which the consumer can translate benefits of decision taken by him on non-financial measure, which is usability. However always taking into account risks associated with the purchase of goods. Among consumers, there are those who prefer to avoid risk. They take purchasing decisions very carefully, hoping that purchased goods will fully satisfy their expectations. But there are also consumers who look for risk. They make a good purchase often on impulse, having limited knowledge about it. Such decisions carry a risk, that the good will not be able to meet their felt needs.

Second of mentioned models -Bettman model [8] is based on different assumptions. It is a model that explains in a comprehensive way, how decisions to purchase are made by the consumer. The author of this model assumed that consumer behavior is going according to a certain program, which is consciously controlled by the consumer. Consumer behavior is characterized by a EKB model. It is a holistic model, with a full solution to the problem, reflecting the process of consumer behavior when making a new purchase decision. It was developed in 1968 by J. F. Engel, D. T. Kollat and R. D. Blackwell [9]. Thename comes from first letters of names of creators of the model. In a comprehensive way they explained behavior of consumers when making purchasing decisions. According to EBK model making purchasing decisions takes place in five phases. These are: problem identification, problem search, assessment of options for choice, decision to purchase a particular good and results of selection. This model accurately explains behavior of consumers in each of five phases. Also Zeithaml and Bitner [10] suggested that the description of decision-making process can also be used for services. Research conducted by Zeithaml and Bitner [10] shows that in the process of purchasing services, these five stages do not occur in linear sequence as usually happens in decision process of purchasing goods. Also in other aspects some differences in the behavior of consumers of services in relation to products consumer have been noted [10].

The behavior of buyers in buying process varies significantly. They are determined by many factors shaping decision-making process of purchase. The process is particularly affected by income and consumer prices of individual goods, as well as numerous socio-cultural, psychological, situational and sex factors [11]. These factors influence whether consumer decides on choice of a specific product or service, and if selected good satisfies his needs. Nevertheless all consumer choices have always some common, universal rules of conduct, reflected in consumer demand. These rules assume that consumers will act in accordance with the principle of rational management and, in its purchasing decisions strives to achieve maximum satisfaction from purchased goods or services.

Young people constitute a significant group of customers which are recipients of an increasingly wider range of banking services. Nature of market of young consumers to a large extent is determined by distinguishing characteristics of young people, their tastes, requirements, purchasing preferences and financial capabilities. Importance of this market is large because young people have significant purchasing power, often own financial resources, they carry out purchases of various goods and services on their own, and also play an important role in purchasing decisions of their peers and members of their households. Young consumers are financial institutions group of customers filling the gap between elder individual customers, entrepreneurs and corporate clients. Financial institutions offer young consumers more and more products and services, and even form an integrated package tailored to their growing requirements. The widest offer in this area are banks. They offer young consumers both traditional as well as modern products and online services. Every year the interest of young consumers in this offer increases.

\section{Development of Electronic Banking in The World and in Poland}

Origins of electronic banking, virtual or otherwise, is seen in the development of the first cash machines (ATM) [12]. Others describe telephone banking and home banking as other forms of virtual banking $[13,14]$. 
Increasing globalization does not allow anyone to live in hope that electronic revolution is not his concern. Electronization of business has more or less impact on the economy of all countries. Modern forms of contact with a bank are slowly becoming the standard in modern world. There is no escape from modern forms of service provision. Development of information technology leaves banks with no choice. They can compete for customers by introducing new solutions, or limit their ability to learn money from transfer of money. Cost of transactions carried out using telephone banking accounts for only $40 \%$ of the cost of a transaction in a branch [13]. In the case of transactions via the Internet, this difference is even greater.

Pioneers of electronic banking in the world are American banks, and in Europe, Nordic banks. It was in Finland in 1984 when first pc banking (home / corporate banking) allowing contact with bank using a computer have been introduced, and Internet transactions were first provided by Finnish and Swedish banks in 1996 [15]. However, it was development of the Internet which allowed access to banking services from own home via the network. The Internet began to play a key role in the economy.

In Poland similarly, the event which allowed development of electronic banking was development of the Internet. It started in the early nineties of twentieth century and was made possible thanks to systems of electronic interchange of EDI data, which allow fast forwarding of any kind of data (eg purchase orders, delivery dates, payment confirmations, etc.). These systems due to high price are limited and available only to large financial institutions [16].

Commercial use of the Internet has developed only in the first decade of twenty-first century. Universality and relatively low cost of online communication compared to previously used solutions, have contributed to popularization of the Internet among banks, businesses and individual clients [17]. Use of Internet for the fully commercial purpose has become possible only since 2002, when the Act on electronic payment instruments came into force. It contains provisions specifically regulating obligations of banks providing their services electronically and protection of personal data of people who use electronic banking services.

In the last decade, development of electronic banking in Poland enabled banks to deliver traditional banking products and services in the modern and most convenient way for customers. This significantly increased both thenumber of bank customers, as well as number of people using phones or computers who perform various banking operations. The annual survey and analysis conducted by the Polish Banks Association shows that over the past 10 years the number of bank customers using e-banking services has increased by more than $40 \%$ [18]. Accurate data on this subject is presented in Figure 1.The report NetB@ @ nu published by the Association of Polish Banks' indicatesthat at the end of the second quarter, the number of customers who have signed a contract for the use of online banking was 27 million people, representing an increase of 16.77 percentyearon year. However, the number of active individual customers amounted to 13.5 million -about 10 percent more than in mid-2014 [18]. From the point of view of customer advantages of electronic bankingare mainly [19]:

- Convenience, for instance easier access to services, better control over personal finances, with the ability to access account status at any time and traceability of operations (account history), ability to use different communication channels (eg landline, mobile phone, e-mail)

- saving time by eg. ability to perform operations at home, no need for filling documents, faster execution of orders

- lower account costs (eg account fee and fee for execution of transfer is several times lower than traditional route)

- elimination of risks associated with transactions in traditional banking, for example theft. 


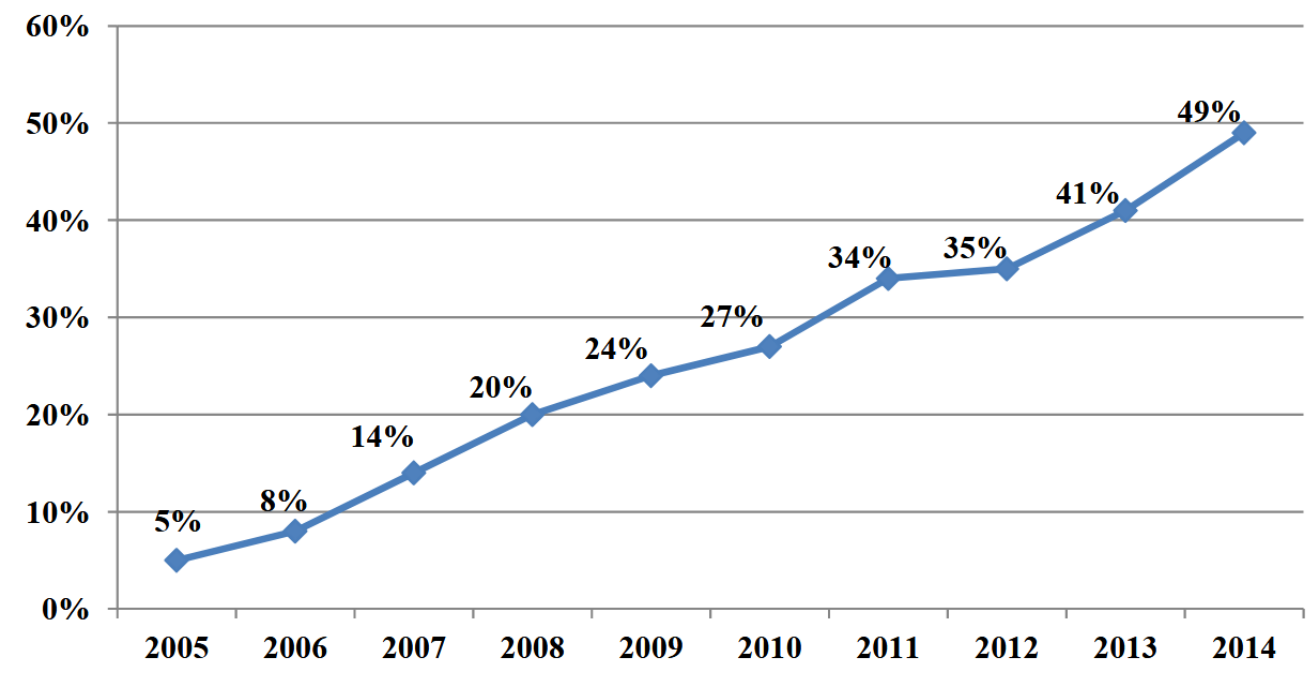

Figure. 1. The percentage of bank customers using electronic banking services in Poland in the years 2005-2014 (\%) [18]

Advantages of electronic banking, which result in benefits for the bank are:

- relatively small, compared to construction of branch network, cost of creating and initiating and maintenance of transaction platform (costs are fixed)

- relatively small variable costs, which are derived from a small number of employees, and other than traditional banking asset structure

- low cost of additional customer service and ease of increasing service capacity

- ability to extend the area of action on regions in which the bank has no physical branches

- shortening the service time for most simple banking operations performed in the mode of self-service

- elimination of threats emerging in traditional banking transactions, eg. a forgery

Online banking also has a number of drawbacks, which are detrimental both to customer and bank. These include for example:

- software bugs (they constitute a serious threat to safety of banks systems in the case of specialized software used exclusively in banks fault can threaten continued operation of the bank, but do not expose it to outside attacks; with regard to bank's activities on the Internet particularly important are software defects responsible for communication with the network, such as web browsers and email programs, because defects in this software allows creators of viruses and other malicious programs to access computers using faulty software)

- increase in activity of eg. computer criminals, risks associated with operation of computer viruses, costs associated with investing in modern software

- limited access to account, and frequent maintenance breaks

- errors in existing online accounts, which limit their functionality (can include for instances lack of visibility of the account balance at the time of transfer)

A significant limitation in using the Internet or mobile services is a matter of safety. Bank accounts of owners of smartphones using mobile banking are more vulnerable to cybercriminals than accounts of people who use traditional desktop. Level of use of information technology in banks is increasing as in every area olife. It is therefore important that as technology develops not to forget about standards of safety and control, or with technical innovations banks raise standards for safety of their operations. Over the past 3.5 years the number of users of mobile banking has increased by approx. $250 \%$ to approx. 4.3 million. On the other hand, percentage of smartphone owners using mobile banking in 2013 was 12 per cent., And in 2015. -already 43 per cent [20].

Growing from year to year interest in electronic banking also contributed to emergence of new services and products and financial techniques, as well as streamlined and accelerated settlement of cash. Most important, however, is that development of electronic banking in recent years introduced a number of significant changes in implementation of payment transactions. These related specifically to contact of customers with bank in terms of payments, automation of instructions and interbank settlements. As a result of technological advances electronic payment systems have 
developed, both within individual countries, as well as in international arena, which greatly accelerated the transfer of funds and information necessary for settlements.

With growing interest in electronic banking, banks have begun to provide more and more services. They were addressed to individual clients, as well as enterprises and institutions whose activities are related to trading currency. Among them it is worth to mention [21]:

- eLending - consumer loans -adoption of loan application by the bank, automatic performance of analysis, and providing the client with information about the results of this analysis takes place by using a special e-credit scoring, which also gives customer opportunity to get acquainted with the bank, check credit worthiness and repayment schedule of the loan

- eBilling - service of electronic management of accounts

- eBroking - brokerage services on the Internet

- personal financial management services

In summary, emergence of computers and telecommunication networks and the use of Internet for full commercial purposes facilitated the transfer of almost entire financial turnover of banks in the virtual area. Development of electronic banking in Poland for many years facilitates the use of traditional services, the content of which has not changed, but methods of service provision are quite different. It also gives the possibility of extending existing services of banks offer with entirely new services resulting from technology capabilities.

Offer of financial institutions, especially banks for young consumers is varied. The main product is a current account, supplemented by bankswith additional services offered depending on customer activity. Young people remaining dependent on their parents, as well as those working, self-sustaining people have the opportunity to take advantage of package offers.

As part of this package, banks offerto young consumers [22]:

- savings and settlement accounts under which young people can perform deposit and cash withdraw operations, issue payment orders and execute domestic and international transfers

- current account auxiliary

- payment cards

- credit cards

Analysis of frequency and method of use of banking products and services by young consumers carried out over several years by the Office of Competition and Consumer Protection indicating that products mentioned above are used by vast majority of youngpeople. Greatest interest among them enjoy services offered by banks together with savings and settlement account. Also the number of young consumers using debit and credit cards increases [23]. Only in the last three years, the interest in such products increased by $55.55 \%$ for credit cards and by $30.86 \%$ with regards to payment cards. Accurate data on this subject are presented in Table 2.

Table. 2. Number of young consumers using basic packages of banking products and services in the years 2012-2014

\begin{tabular}{|l|c|c|c|c|}
\hline \multirow{2}{*}{$\begin{array}{c}\text { Products and } \\
\text { services banking }\end{array}$} & $\mathbf{2 0 1 2}$ & $\mathbf{2 0 1 3}$ & $\mathbf{2 0 1 4}$ & $\begin{array}{c}\text { Dynamics } \\
\text { of change } \\
\mathbf{2 0 1 2 / 2 0 1 4}\end{array}$ \\
\cline { 2 - 5 } & 1259273 & 1302022 & 1314302 & $+4,37 \%$ \\
\hline $\begin{array}{l}\text { Deposits and cash } \\
\text { withdrawals }\end{array}$ & 1213070 & 1240011 & 1297147 & $+6,93 \%$ \\
\hline Domestic transfers & 572650 & 712321 & 785398 & $+37,15 \%$ \\
\hline $\begin{array}{l}\text { PLN auxiliary } \\
\text { account }\end{array}$ & 544716 & 614551 & 670419 & $+23,07 \%$ \\
\hline Direct debit & 684386 & 742201 & 895562 & $+30,86 \%$ \\
\hline Cards & 377111 & 488847 & 586617 & $+55,55 \%$ \\
\hline Credit cards & & &
\end{tabular}


Young consumers receive also from banks many modern products and online services. From year to year they enjoy more and more interest.

\section{Testing Method and Discussion on Results}

The survey was conducted between January and February 2016 in the form of electronic questionnaire sent out to students of the Czestochowa University of Technology and other young people through social media. Replies were received from 201 people. The study involved mostly people aged 18-30 years. People over 30 years old accounted for only $6 \%$ of all respondents. The most numerous group representing $72.5 \%$ were young people aged 21-25 years.

Respondents were mostly women (70\%), only $30 \%$ of answers were provided by men. Important from the point of view of research on consumer behavior and preferences of payment is also a look at the respondent's place of residence. In this study, the largest group of respondents were urban inhabitants (72.5\%). Others participating in the study were the rural population $-27.5 \%$.

Behavior of young customers in e-banking services is extremely impacted by their financial situation. In own assessment of respondents on their financial situation is mostly good (59.3\%). However, up $30.7 \%$ of respondents indicated that it is only adequate, and $1.5 \%$ that poor. Only $8.5 \%$ rated their financial situation as very good.

Among respondents only few, because $2 \%$ do not use bank services. These individuals indicated that young man begins to use services of the bank when it begins to receive a scholarship or start to work. It can be concluded that, unfortunately, they do not receive income by now. Remaining respondents pointed out that an income resulting from a job or scholarship is an incentive to use bank's services $(68.3 \%)$. As many as $19.1 \%$ of respondents believe that under the influence of peers using such services, they also consider what benefits it could bring. Among other factors influencing decision to use services of the bank respondents mention a possibility of making payments online, residence far from the family, easier control of income and expenditure, requirements of many institutions for online payments, were mentioned. Respondents asked about the best source for information about the bank's offer of the bank frequently pointed out to opinion of other users $(33.3 \%)$ or website of the bank $(25.4 \%)$. According to respondents of considerable importance also have direct conversation with consultant in a bank branch.

Answering the question of what banking products are most popular among young people, thevast majority (184 persons) indicated personal accounts, and 47 people also pointed to credit cards. In third place subjects mentioned term deposits (23 people). Little popularity among young people, in opinion of respondents, have consumer loans or mortgages. This is probably due to lack of creditworthiness of youth. Almost $50 \%$ of respondents believe that a very large or large importance when choosing a bank has lack of requirements of bank to have a minimum monthly income.

Respondents do not use telephonebanking (operations performed using landlines), while they most commonly use terminal banking, i.e. operations carried out by payments cards (50\%). Almost as often (46.1\%) perform operations via the Internet. Surprising is only a 3.9\% share of mobile banking (operations using mobile phones).

Among the most commonly used online banking services respondents listed: checking account balances (125 people), paying bills by standing orders or direct debits and transactions made with the card. Young customers of electronic banking as its biggest advantages mention saving time, and access to account 24 hours per day. They appreciate also lack of queues at bank branches and speed of transaction. Among disadvantages young people show the need to access to the Internet and no access to account because of maintenance of network. 61 people from among respondents believe that the security system of electronic banking services is insufficient.

\section{Summary}

To summarize the discussion of consumer behavior in a virtual environment it should be emphasized that the Internet has created a specific behavior only for this medium -ability to create individual products at prices of bulk products, ability to quickly and effectively find niche products, fast comparison of prices, opportunity to review thousands of user reviews on the topic. In other words, Internet allowed to collect more information in less time. Therefore it can be said that the biggest change resulting from operation in a virtual environment took place in decision-making process of the consumer at the stage of looking for information and assessment of alternatives to choose from, although questioned young customers appreciate direct contact with the consultant at the stage of gathering 
information about a product. However, there is no doubt that the Internet is one of the most important factors affecting current consumer behavior, and its role will increase year over year.

The Internet has become a new medium for banking services. It opened a prospect of easier, faster and less expensive reaching existing and potential customers. The extent to seize this opportunity is up to banks. Banks that embrace the Internet as a form of provision of services have a chance to achieve a competitive advantage.

The study has shown that online banking is the form of provision of services within electronic banking most preferred by young people in Poland. From banks point of view it is characterized by sufficient level of security, however we must remember that it requires appropriate technical conditions on the customer side. In the opinion of respondents telephone banking is irrelevant, and mobile banking is currently used on a small scale most likely due to a relatively low level of security, or lack of youth access to mobile Internet.

In context of increasing requirements of people using modern banking, specialized solutions can help banks retain more customers by protecting not only online and mobile transactions, but also integrity of their brand.

\section{References}

[1] A. Freeman, Technology in finance. The Economist, October 26, 3-26, 1996.

[2] D. B. CraneandZ. Bodie, The Transformation of Banking: Forms follows function. Harvard Business Review, March April, 109-117, 1996.J.C. Mowen, Consumer Behavior, Macmillan, 1993.

[3] G. AntonidesandW.F. Raaij, Zachowanie Konsumenta. Podręcznik Akademicki. Wydawnictwo Naukowe PWN, Warszawa, 2003.

[4] A. FalkowskiandT. Tyszka, Psychologia zachowań konsumenckich, Gdańskie Wydawnictwo Psychologiczne, Gdańsk, 2009.

[5] E. Kieżel, Zmiany zachowań, a racjonalność w postępowaniu polskich konsumentów, In: Decyzje konsumentów i ich determinanty. Ed. E. Kieżel, Wydawnictwo Akademii Ekonomicznej, Katowice, 2001.

[6] J. Szczepański, Wydajność pracy, a konsumpcja, Nowe Drogi, no. 11, 1976.

[7] J.W.Payne, J.R. BettmanandE.J. Johnson, The Adaptive Decision Maker, Cambridge University Press, 1993.

[8] J.F. Engel, D.T. KollatandR.D. Blackwell, Consumer Behavior, Holt, Reinhart \& Winston, New York, 1968.

[9] V.A. Zeithaml, and M. J. Bitner, Services Marketing: Integrating Customer Focus across the Firm, 3rd ed., McGraw-Hill Irwin, Boston, MA, 2003.

[10]L. Piersiala, Strategie zakupowe konsumentów uwarunkowane płcią Process decyzyjny konsumenta, Zeszyty Naukowe Politechniki Śląskiej Organizacja i Zarządzanie, Issue 68, No 1905,2014.

[11] R. Kass, Looking for the Link to Customers. Bank Systems and Technology, February, 64, 1994.

[12] S. Talmor, New life for dinosaurs, The Banker, Vol. 145, September, 75--78, 1995.

[13]H. Sraeel, Virtual banking: Gearing up to play the no-fee retail game. Bank Systems and Technology, July, 20-22, 1995.

[14] Ch. Brown-Humes, The dinosaurs are not going to die, The Banker supplement, No.3, 2000.

[15] A. Pamuła, Bankowość electroniczna, in: Społeczeństwo informacyjne. Ed. J. Papińska-Kacperek. PWN, Warszawa, 2008.

[16]C. Żurak-Owczarek, Technologie informacyjne determinantą współczesnego biznesu, Wydawnictwo Uniwersytetu Łódzkiego, Łódź, 2011.

[17] http://prnews.pl/m/upl/2015-05/ elek.png (Access on: 10.08.2015).

[18]Bankowość electroniczna, http://www.naukowiec.org/wiedza/ekonomia/bankowosc-elektroniczna_2389.html(Access on: 28.12.2015)

[19] http://wyborcza.biz/biznes/1,147752,19172002,knf-korzystasz-z-banku-na-smartfonie-jestes-zagrozony.html\#ixzz40XgiYLy p(Access on: 02.02.2016) 